\title{
ГЕОГРАФІЯ
}

UDC 911.2:911.9:528.9

Ivan Platonovich Kovalchuk,

Doctor of Sciences (Geography), Professor, Head of the Department of Geodesy and Cartography,

National University of Life and Environmental Sciences of Ukraine,

17 Vasylkivska St., Building 6, Kyiv, 03040, Ukraine, e-mail: kovalchukip@ukr.net, https://orcid.org/0000-0002-2164-1259;

Oksana Ivanivna Mykytchyn,

$\mathrm{PhD}$ (Geography), Senior Lecturer, Ivan Franko State Pedagogical University of Drohobych,

23 T. Shevchenko St., Drohobych, Lviv region, 82100, Ukraine,

e-mail: omykytchyn@ukr.net, https://orcid.org/0000-0002-8146-5947;

Andrii Ivanovich Kovalchuk,

PhD Student, Taras Shevchenko National University of Kyiv,

2a Akad. Glushkov Av., Kyiv, SME-680, Ukraine,

e-mail: kovalchuk94a@gmail.com, https://orcid.org/0000-0001-6448-4727

\section{GEOINFORMATION MODELING OF ANTROPOGENIC TRANSFORMATION OF THE BASIN GEOSYSTEMS (CASE STUDY OF DNISTER RIGHT TRIBUTARIES)}

І. П. Ковальчук, О. І. МИкИтчин, А. І. КовальчК. ГЕОІНФОРМАЦІЙНЕ МОДЕЛЮВАННЯ АНТРОПОГЕННОЇ ТРАНСФОРМАЦЇ̈ БАСЕЙНОВИХ ГЕОСИСТЕМ (НА ПРИКЛАДІ ПРАВОБЕРЕЖНИХ ПРИТОК ДНІСТРА). У СТАТті акцентовано увагу на методах кількісного оцінювання антропогенного навантаження на річково-басейнові геосистеми. Зокрема, розглянуто методики, які базуються на визначенні співвідношеннях різних видів землекористування (Ф.М.Милькова, С. Клементової та В. Гейніге, П.П. Борщевського, М.В. Боярин, Н.М. Рідей і Д.Л. Шофолова) і ті, в яких використовуються вагові коефічієнти, щуо вказують на ступінь і глибину перетворення природи кожним видом землекористування (П.Г. Щищенка, А.М. Третяка). На прикладах річково-басейнових геосистем Бережниці та Бистриці (Прикарпатських правобережних приток Дністра) за допомогою геоінформаційного моделювання оцінена репрезентивність результатів, отриманих за циими методиками, відзначено особливості та переваги і недоліки кожної з оиінюваних методик. Для досліджуваних геосистем визначено ступінь антропогенної трансформації, геоекологічний стан агроландшафтів, геоекологічну стабільність та антропогенну трансформацію, виявлено спільні закономірності та відмінні особливості річковобасейнових геосистем. В ході роботи вирішувалося питання вибору оптимальних структурних одиниць геопростору, в розрізі яких варто здійснювати аналіз антропогенного навантаження, а також способи наповнення бази даних для картографічного моделювання. На прикладі річково-басейнової геосистеми Бережниці доведено важливість оцінки природних об'єктів (в даному випадку річкових басейнів) у розрізі природних структурних одиниць нижчого порядку (підбасейнів). Оскільки в даному випадку ускладнюється збір інформачї про структуру землекористування, яка зазвичай формується у розрізі адміністративних одиниць, з метою наповнення бази даних обірунтована дочільність використання даних дистанційного зондування Землі. Одержані результати свідчать про те, щзо вагома роль у стабілізації антропогенного навантаження відводиться збереженню лісових масивів, які властиві верхнім ділянкам басейнів, зменшенню розораності нижніх частин басейну, підтримці в належному стані меліоративних каналів, зменшенню впливу промисловості на довкілля та уникненню концентрації значної кількості промислових об'єктів в одній структурній одиниці - суббасейні.

Ключові слова: річково-басейнові геосистеми, геоінформаційне моделювання, структура землекористування, антропогенна трансформація.

И. П. Ковальчук, О. И. МикИтчин, А. И. Ковальчук. ГЕОИНФОРМАЦИОННОЕ МОДЕЛИРОВАНИЕ АНТРОПОГЕННОЙ ТРАНСФОРМАЦИИ БАССЕЙНОВЫХ ГЕОСИСТЕМ (НА ПРИМЕРЕ ПРАВОБЕРЕЖНЫХ ПРИТОКОВ ДНЕСТРА). В статье акиентировано внимание на методах количественного оценивания антропогенной нагрузки на бассейново-речные геосистемы. В частности, рассмотрены методики, основанные на определении соотношений различных видов землепользования (Ф.М. Милькова, Е. Клементовой и В. Гейниге, П.П. Боршевського, М.В. Боярин, Н.М. Ридей и Д.Л. Шофолова) и методики, которые используют весовые коэффициенты, указываюшие на степень и глубину преобразования природы суббасейна каждым видом землепользования (П.Г. Щищенка, А.М. Третяка). С помощьью геоинформационного моделирования на примере бассейново-речных геосистем Бережницы и Быстрицы (Прикарпатских правобережных притоков Днестра) оченена репрезентативность результатов, полученных по каждой из методик, отмечень их особенности и преимущества. Для исследуемых геосистем определены степень антропогенной трансформации, геоэкологическое состояние агроландшафтов, геоэкологическая стабильность и антропогенная трансформированность, выявлены общце закономерности и отличительные особенности бассейново-речных геосистем. В ходе работы решался вопрос выбора оптимальньх структурных единии, в разрезе которых следует осуществлять анализ антропогенной нагрузки и избирать способы наполнения базы данных для геоинформачионно-картографического моделирования. На примере бассейново-речной геосистемь Бережныци доказана важность оченки состояния природно-хозяйственных объектов (в данном случае речных бассейнов) в разрезе структурных единиц низшего порядка (подбасейнов). Поскольку в данном случае осложняется сбор информации о структуре землепользования, которая обычно формируется в разрезе административных единии, с иелью наполнения базы данных предложено использовать материаль дистанционного зондирования Земли. Полученные результать свидетельствуют о том, что значительная роль в стабилизачии антропогенной нагрузки отводится сохранению лесных массивов,

(C) Kovalchuk I. P., Mykytchyn O. I., Kovalchuk A. I.

https://doi.org/10.26565/2410-7360-2019-51-09 
которые свойственны верхним частям бассейнов, уменьшению степени распаханности нижних частей бассейна, поддержанию в надлежащем состоянии мелиоративных каналов, уменьшению влияния промышленности на окружающую среду и избежанию кониентрации промышленных объектов в одной структурной единице - суббасейновой геосистеме.

Ключевые слова: бассейново-речные геосистемы, геоинформачионное моделирование, структура землепользования, антропогенная трансформачия.

Formulation of the problem. It is believed that there is no place on the globe that hasn't been affected by human activity. Even the most remote areas are polluted by unusual substances due to the global circulation of air and water. Economic development extends not only horizontally, but also actively penetrates into the thickness of rocks. It changes the state of not only biotic components of geosystems, but also abiotic, affecting the development of natural complexes, which are transformed into anthropogenically modified, and then into anthropogenic complexes. Very often, these changes lead to irreversible processes with negative consequences both for ecosystems, and for people and society. Under such conditions, the problem of assessing the state and transformation of natural systems under the anthropogenic pressure becomes more and more relevant and of interest to a wide range of specialists. The growth of anthropogenic pressure is, in particular, observed within the territory of our country and is characterized by the destruction of landscape systems due to rapid deforestation, unreasonable increase of arable land areas, large-scale urbogenic and man-made influences. Anthropogenic changes have occurred in all the natural components - relief, relief formation deposits, flora and fauna, soil cover, surface waters and groundwater, etc. Therefore, complex approach is needed to assess these consequences. From such point of view, river basins are perfect objects for systematic geoenvironmental studies, as they are represented by holistic integrated entities [10-12]; therefore, we consider it most appropriate to study anthropogenic transformation of the environment just in the context of these structural units of geographical space.

Analysis of recent research and publications. Studies of territorial complexes anthropogenic transformation are topical considering the increasing technogenic influences on the environment and are carried out by a number of landscape studies schools in Ukraine. Depending on the main idea of anthropogenic changes research, two conceptual scientific approaches are distinguished. Proponents of the first approach base their research on the concept developed by F.M. Milkov [16] that states that the changes in any component of the landscape very quickly propagate to all other components and to the landscape complex as an whole $[4 ; 6 ; 7]$. Followers of L.S. Berg, N.A. Solntsev and A.G. Isachenko support the idea of inequality of the components of nature by the force with which they influence each other. This approach and the concept of anthropogenic transformation of geosystems were elaborated by L.I. Voropay, V.P. Korzhik, M.M. Kunitsa, Y.P. Skrypnyk, V.N Gutsulyak, Y.A. Ivanov, I.P. Kovalchuk, I.S. Kruhlov, P.G. Shyshchenko [6; 13; 14; 21; $22 ; 26 ; 27]$. Regional studies of anthropogenic changes of the environment were conducted in works of I.P. Kovalchuk, S.I. Kukurudza, A.V. Melnyk, P.I. Stoiko, I.B. Koynova, I.S. Kruhlov, M.M. Prikhodko, M. M. Proskurnyak, L.Y. Sorokina [9; $10-12 ; 14 ; 15 ; 20 ; 22 ; 26 ; 27]$. The issues of anthropogenic pressure and of the estimation of river basins transformation are highlighted by V.I. Vishnevsky, I.P. Kovalchuk, O.V. Kirilyuk, O.A. Liho, Y.M. Andreichuk, A.V. Mykhnovych, O.V. Pylypovych, L.P. Kurhanevych [3; 7; 8; 10-12; 15-19; $23 ; 25]$ and others. In foreign geography, these questions are raised by F. Gossain [29], J. Batista and B. Barros [28], J. Lautze, S. Phiri, V. Smakhtin et al. [30], J. Lee et al. [31], L. Liu et al. [32]. Foreign authors analyze the problem in the context of mapping support of the sustainable development of the Zambezi river basin system [30; 34], mapping the properties of soils of the studied basins [32], search for the most accurate and economical methods for determining water discharges [31], developing a semi-automated delimitation algorithm for protected areas along watercourses [28], modeling the geoenvironmental state of river basin system with the use of remote sensing; the investigation by means of the indicative properties of the hydrographic network in the absence of hydrological observation points and water flow data, [29]. J. Szpikowski [33], while investigating the Perznica basin, located in the northwest of Poland, over the course of a number of years of nature change has used such methods as the analysis of archival large-scale maps, digitization of topographic maps, vectorization of spatial objects and mapping the types of terrestrial surfaces and their changes for the 200 -year period.

At the same time, not all aspects of the problem are studied with the same degree of detail. New opportunities are being opened using methods of remote sensing to obtain high-quality information, as well as technologies of geoinformation and cartographic modeling of the respective processes. The article highlights these aspects of the anthropogenic transformation study of river-basin systems environment.

Quantitative methods for evaluating the degree of anthropogenic pressure that take into account the structure of land use, natural and anthropogenic el- 
ements, are described in the works of I.P. Kovalchuk, M.A. Petrovska, F.M. Milkov, P.G. Shyshchenko, A.M. Tretyak, P.P. Barshchevsky, N.M. Ridey and D.L. Shofolov, M.V. Boyarin, Y. Clementova and V. Heinige et al. $[1-2 ; 5 ; 8-13 ; 15-$ $19 ; 21 ; 23 ; 25]$.

There are two main approaches to determining the anthropogenic pressure by quantitative methods, which follow from two different conceptual directions of the study. The first approach is based on calculations of the ratio of areas under different types of land use; the basis of the second approach is the use of weighting factors that indicate the degree of conversion of the environment by various types of economic activity.

Among the methods based on the use of the first approach the most commonly applied method is that by F.M Milkov [16], which determines the ratio of areas of natural and anthropogenically modified territorial complexes. Landscape systems fall into the categories by the ratio of anthropogenic and natural unaltered lands: antropogenic (natural land cover occupies less than $25 \%$ of total area), naturalanthropogenic (25-50\%), anthropogenic-natural (50$75 \%)$ and natural landscape systems (75\%). Similar in essence is the definition of the transformation coefficient of the territory in the method proposed by M.V. Boyarin [2]. This coefficient reflects the proportion of anthropogenically altered areas in the land use structure of the studied basins.

The relative proportion of arable lands to the group of sustainably used lands like perennial plants, hayfields, pastures, land for shelter belts, defines the geoenvironmental condition of agricultural landscapes (Table 1) (proposed by N.M. Ridey and D. L. Shofolov [21]) and the level of ecological balance of the territory, proposed by M.V. Boyarin [2]. These two models are very similar. Their only difference is in the approach to classification, since the definition of the territory balance considers the multiplicity of cultivated lands ratio, while the geoenvironmental state determination of agricultural landscapes is based on the percentage of arable land and land of sustainable use. The disadvantage of these two techniques is the fact that they take into account only some types of land use, among those present in the study area. This leads to an exclusion of the study areas where no land use types included in this calculation are present. It also complicates automatic calculation when the area in the denominator equals zero.

Due to the fact that these models take into account only the ratio of arable land and lands of sustainable use, we consider it appropriate to consider all the types of land use represented in the study area in the analysis of anthropogenic pressure indicators.

This approach is used in the methodology for determining the coefficient of environmental stability of the territory, proposed by E. Clementova and V. Heinigge [9] This coefficient is defined as the ratio of areas of environmentally stable lands to areas of environmentally unstable lands. A higher coefficient means a higher rate of stability of the territory. By the coefficient value of ecological stability five states can be distinguished in the studied areas. If the coefficient of ecological stability of the territory $<0,5$ - the territory is unstable with apparent instability, 0,5-1,0 - unstable, 1,0-3,0 - conditionally stable; 3,0-4,5 - stable; > 4.5 - stable with pronounced stability.

Whilst being similar to the methodology by $\mathrm{E}$. Klementova and V. Heinige, the methodology for calculating the environmental stability of the territory (1), proposed by P. P. Borschevsky [1] is based on a different approach and takes into account the weight coefficients of different types of land use:

$$
\text { Ces }=\frac{\sum_{n}^{1} S i C i}{\sum_{n}^{1} S i},
$$

where $\mathrm{C}_{\mathrm{es}}$ - coefficient of environmental stability of the territory, $\mathrm{C}_{\mathrm{i}}$ - coefficient of environmental properties of the land type of i kind (Table 2), $S_{i}-$ area of land type of $\mathrm{i}$ kind, ha; $\mathrm{n}$ - number of indicators. The values of the coefficient $\mathrm{C}_{\mathrm{es}}$ are given in Table 2.

If the obtained value of $\mathrm{C}_{\mathrm{es}}$ is less than 0.33, then land use is deemed environmentally unstable; if $\mathrm{C}_{\mathrm{es}}$ varies from 0.34 to 0.50 , land use is considered to be continiously unstable; if it is in the range of 0.51 to 0.66 then it falls into the category of medium stability, and if $\mathrm{C}_{\mathrm{es}}$ exceeds 0.67 , then the land use is environmentally sustainable.

Table 1

Scale for assessing the environmental state of agrolandscapes by the ratio of land use types

(N. M. Ridey, D. L. Shofolov) [21]

\begin{tabular}{|c|c|c|}
\hline \multicolumn{2}{|c|}{ The share of land \% } & \multirow{2}{*}{ State } \\
to the sum of the area of arable lands and the lands of sustainable use & \\
\hline Arable lands & Lands of sustainable use & Optimal \\
\hline$<20$ & $>80$ & Good \\
\hline $20: 35$ & $65: 80$ & Adequate \\
\hline $35: 55$ & $45: 65$ & Inadequate \\
\hline $55: 70$ & $30: 45$ & Critical \\
\hline$>70$ & $<30$ & \\
\hline
\end{tabular}


The environmental properties coefficients value for the different types of lands [1]

\begin{tabular}{|l|c|}
\hline \multicolumn{1}{|c|}{ Land type } & C \\
\hline Built up area and roads & 0 \\
\hline Arable land & 0,14 \\
\hline Vineyards & 0,29 \\
\hline Shelter belts & 0,38 \\
\hline Perennial plantations, shrubs & 0,43 \\
\hline Household plots & 0,5 \\
\hline Hayfields & 0,62 \\
\hline Pastures & 0,68 \\
\hline Ponds and marshes of natural origin & 0,79 \\
\hline Forests of natural origin & 1 \\
\hline
\end{tabular}

The methods by A.M Tretyak [24] and P.G. Shyshchenko [26] are widely used to determine the degree of anthropogenic transformation using weight coefficients.

These techniques are distinguished by the fact that in the first, which is calculated by the formula (2), different weight coefficients for different types of land use are used:

$$
C a p=\frac{\sum_{n}^{n} s p}{\sum_{n}^{1} s},
$$

where Cap - coefficient of anthropogenic load; $S_{1^{-}}$ $\mathrm{S}_{\mathrm{n}}$ - area of land with a certain level of anthropogenic loading; $\mathrm{p}_{1}-\mathrm{p}_{\mathrm{n}}-$ evaluation ranks of the corresponding area (the 5-point scale is shown in Table $3) ; n$ - number of indicators.

On the other hand, in the method by P.G. Shyshchenko [26] simultaneously with the rank of transformation another correctional coefficient is being taken into the equation - the depth of transformation of the investigated area.

$$
\text { Cat }=0,01 \sum r_{i} p_{i} q_{i} \text {, }
$$

where Cat - coefficient of anthropogenic transformation; $r_{i}-$ the rank of anthropogenic transformation of the territory by the i-type of land use; $q_{i}-$ index of the transformation depth of territory (tab. 4.); $\mathrm{p}_{\mathrm{i}}$ - area of rank, $\% ; \mathrm{n}$ - number of land use types within the studied territory.

The classification results also differ from one method to the other.

According to the coefficients of anthropogenic load, obtained by A.M.Tretyak's method, the following categories of territories by the degree of transformation are distinguished: the least developed (Cat up to 2,5); weakly transformed (Cat 2.6 - 3.0); transformed (Cat 3.1-3.5); moderately transformed (Cat $3.6-4.0$ ); strongly transformed (Cat 4.1-4.5);

Table 3

Ranking assessment of the degree of anthropogenic pressure on land resources [24]

\begin{tabular}{|l|c|}
\hline \multicolumn{1}{|c|}{ Lands } & Rank \\
\hline Lands used by of industry, transport, built-up lands & 5 \\
\hline Arable lands, perennial plantations & 4 \\
\hline Natural forage lands, grass-covered gulches & 3 \\
\hline Shelter belts, shrubs, forests, swamps, submerged lands & 2 \\
\hline Micro-reserves & 1 \\
\hline
\end{tabular}

Table 4

Weight ratios of the rank and depth indices of landscapes anthropogenic transformation [26]

\begin{tabular}{|l|c|c|}
\hline \multicolumn{1}{|c|}{ Types of land use } & $\mathbf{q}_{\mathbf{i}}$ & $\mathbf{r}_{\mathbf{i}}$ \\
\hline Protected areas & 1 & 1 \\
\hline Forests & 2 & 1,05 \\
\hline Swamps and wetlands & 3 & 1,1 \\
\hline Meadows & 4 & 1,15 \\
\hline Gardens and vineyards & 5 & 1,2 \\
\hline Arable land & 6 & 1,25 \\
\hline Rural built-up areas & 7 & 1,3 \\
\hline Urban built-up areas & 8 & 1,35 \\
\hline Water reservoirs, channels & 9 & 1,4 \\
\hline Lands of industry & 10 & 1,45 \\
\hline
\end{tabular}


very strongly transformed (Cat 4,6 and more).

The P.G. Shyshchenko's method divides territories by their Cat: at Cat 2,00-3,80 the territory is being referred as weakly converted; at Cat 3,81-5,30 - as converted; at Cat 5,31-6,50 - as moderatelyconverted; at Cat 6,51-7,40 - as highly converted; at Cat 7.41-8.00 - as excessively converted.

All these data indicate that these two methods are different and, accordingly, geoinformation models created by them will look different. The analysis of these two methods indicated [24; 26] that P.G. Schyshchenko's method reflects the situation more accurately, since it takes into account antropogenic pressure, the state of agro-landscapes, the balance and stability of land use.

In 1980s, P.G. Shyshchenko created a map of landscape anthropogenic transformation on the national level [27]. Subsequently, his methodology gained popularity and was used at the regional level, in particular for the territorial analysis of anthropogenic transformation of the natural environment in certain regions (Kherson, Lviv, Ivano-Frankivsk, Volyn, etc.), owing to the use of official statistical indicators that are collected by administrativeterritorial principle.

Identification of previously unresolved parts of the general problem. In assessing the anthropogenic pressure on natural objects, a particular method is usually chosen, based on existing statistical information in the context of administrative units. Since the administrative division is not representative for the study of river-basin geosystems, it is important to choose an optimal method among the existing ones, to isolate the structural natural subsystems of the lower ranks, and to form within them data on anthropogenic changes in the environment. This approach is optimal and is implemented in our study.

Formulating the purpose of the article. The purpose of this work is to analyze the anthropogenic transformation of Subcarpathian river-basin geosystems by means of geoinformation modeling using various methods of quantitative estimation of anthropogenic pressure, to compare the modeling results on the basis of administrative-territorial and natural units, to select the optimal structural units for the study of anthropogenic changes in basin geosystems.

Exposition of the main research material. Using F.M. Milkov's method, based on the determination of the ratio of natural areas to anthropogenically-altered natural-territorial complexes, we have analyzed the anthropogenic transformation of the natural environment both for administrative divisions (Stryi district of Lviv region) and natural geosystems - the river basins (the basins of the Berezhnytsia river (Lviv region) and Bystrytsia (Ivano-
Frankivsk region)). Both rivers are the right tributaries of the Dniester, but with different areas of their respective basins.

By comparing the results of the implemented researches, it is possible to clearly state the expedience of using the basin approach to the study of natural complexes anthropogenic transformation.

Figure 1 shows the model of anthropogenic transformation of the natural environment, created for the same territory, but using different approaches. In this model, part of the Berezhnytsia river ba$\sin$ is located within the administrative-territorial units of the Stryi district, which are a part of the studied basin. In the first case, the calculation of anthropogenic transformation is based on the data which are provided by the administrative-territorial principle and are contained in the form "6-zem", which contains the statistical information on the availability of lands and their distribution by land users. The analysis of anthropogenic transformation in the other approach was carried out within the limits of natural, not administrative, units, which were sub-basins of the thalweg network. The choice of such units is due to the specific feature of Berezhnytsia river basin structure: one third of the studied basin surface is fully meliorated and is lacking any natural watercourses. Therefore, anthropogenic pressure analysis should be carried out on the basis of pre-allocated (on a topographic map of a large scale) water catchments of the natural watercourses network, and in the reclaimed portion of the basin on the basis of delineated basins of reclamation channels. This will, to a greater extent, ensure the homogeneity of the studied units and the possibility of comparative analysis of their conditions from the standpoint of nature components anthropogenic transformation.

However, analyzing anthropogenic transformation using natural units, one has to face the problems caused by the lack of statistical information that reflects the economic activity within their boundaries. It is possible to solve this problem using remote sensing data, which allows to estimate the land use structure of the study area. A model of Berezhnytsia basin system anthropogenic transformation in terms of sub-basins created by us, was thus based on remote sensing data.

The overlay analysis used to compare these two approaches suggests a significant difference between the results obtained, since the use of the administrative-territorial units even of the lowest level did not allow to correctly assess the anthropogenic transformation of natural objects, boundaries of which for the most part do not coincide with the boundaries of the administrative divisions. In particular, the indicator of anthropogenic transformation of the natural environment of the rural coun- 
cils indicates that there are no natural surfaces in them, while in fact, they amount to $15 \%$ in the investigated part of the basin (according to the model of anthropogenic transformation of sub-basins).

A similar situation has occurred on the model of the basin system anthropogenic transition created by us using the method by P.G. Shyshchenko (Fig. 2). The use of administrative-territorial units as an estimated geospatial objects shows the excessive transition of the natural environment in the basin exclusively within town Morshyn. The model of anthropogenic transformation in the context of subbasins allows us to visualize the over-transformed parts of the basin, which are present on the right bank throughout the length of the river, and cover vast areas downstream of the town of Dashawa. Sub-basins with excessively transformed natural environment are present within the weakly transformed natural landscapes of rural councils.

This approach should be utilized for the river basins, where it is difficult to allocate equal structural units. In the case of studying a river basin with large area and dense river network, this approach will yield a mosaic picture, which complicates the identification of the basic regularities in the analysis. Therefore, in order to determine the anthropogenic transformation of the basin geosystem of the Bystrytsia River, we have identified sub-basins with homogeneous geomorphological and hydrological features that allow us to trace the differences between the main parts of the basin.

A series of GIS models was created to interpret the anthropogenic transformation of the basin geosystems of Berezhnytsia and Bystrytsia rivers (Figure 3); they show that the largest changes have occurred in the basins of a higher ranks. Regarding the spatial location, the upper part of the basins is dominated by natural and natural-anthropogenic sub-basins with man-made changes that consist of the deforestation and the presence of small settlements; and anthropogenic impact is rising downstream. In particular, on the left bank of the middle reaches the share of anthropogenic sub-basins increases from Berezhnytsia village in Stryj district to the settlement Dashawa (by increasing the area of agricultural land and due to the location of the settlements exclusively on the left bank). The most transformed is the lower, actively reclaimed part of the basin, where anthropogenic sub-basins predominate. This situation has arisen due to the significant plowing of the land, which was facilitated by the drainage reclamation and the flat terrain of the basin.

As for the basin of Bystrytsia, there are three groups of sub-basins: natural-anthropogenic (the highest part of the basin), anthropogenic-natural (mountainous part) and anthropogenic (low-altitude and plain parts of Bystrytsia river basin system RBS).

Models of the geoenvironmental state of agricultural landscapes (Figure 4) indicate the domination of territories with a satisfactory, good and optimal condition of agrolandscapes in the upper and forested parts of the basins (due to low percentage of arable land in mountain parts, domination of forests, meadows, pastures and swampy areas), and an increase in the share of territories with unsatisfactory and critical condition on plain areas. Here, among the important factors influencing the environmental state of agricultural landscapes are: the fairly high level of agricultural land cultivation, low fertility of background soils, high acidity, active manifestation of degradation processes, contamination by mineral fertilizers and remedies for protecting agricultural crops from pests, diseases and weeds, etc. The worst conditions of agro-landscapes are observed in the reclaimed valleys of the main rivers and their tributaries.

The model of geoenvironmental stability, based on the ratio of stable and unstable lands (Figure 5), shows contradictory results for the two basins, due to the fact that considerable area in the basin of the Berezhnytsia river appears to be an unstable territory with pronounced instability. This is explained by the fact that in subbasins located in forest lands, there are widespread forest cutting, as well as forest clearings and roads building. Instead, such a model for the Bystrytsia basin, in comparison with the model created by P.P. Borshchevsky (Figure 6), indicates the presence of stable territories in the most upper and forested part of the basin, since they are less developed than the forested territories in the basin of Berezhnytsia.

Continuously unstable conditions are widespread among subbasins located near the settlements that border geoenvironmentally unstable areas.

Determination of the degree of the natural environment anthropogenic transformation in sub-basins was carried out using two methods - one of A.M. Tretyak [24] (Fig. 7) and the other of P.G. Shyshchenko [26] (Fig. 8). In the method by A.M. Tretyak weight coefficients for different types of land use are used, and P.G. Shyshchenko's method takes into account the depth index and the rate of conversion for each type of land use. Accordingly, the results are different.

An analysis of the map compiled in accordance with A.M. Tretyak's technique, shows that the anthropogenic transformation of the Bystrytsia river basin grows downstream and changes from the weak to the average type.

The Berezhnytsia river basin includes the least transformed territories and highly transformed ones, 


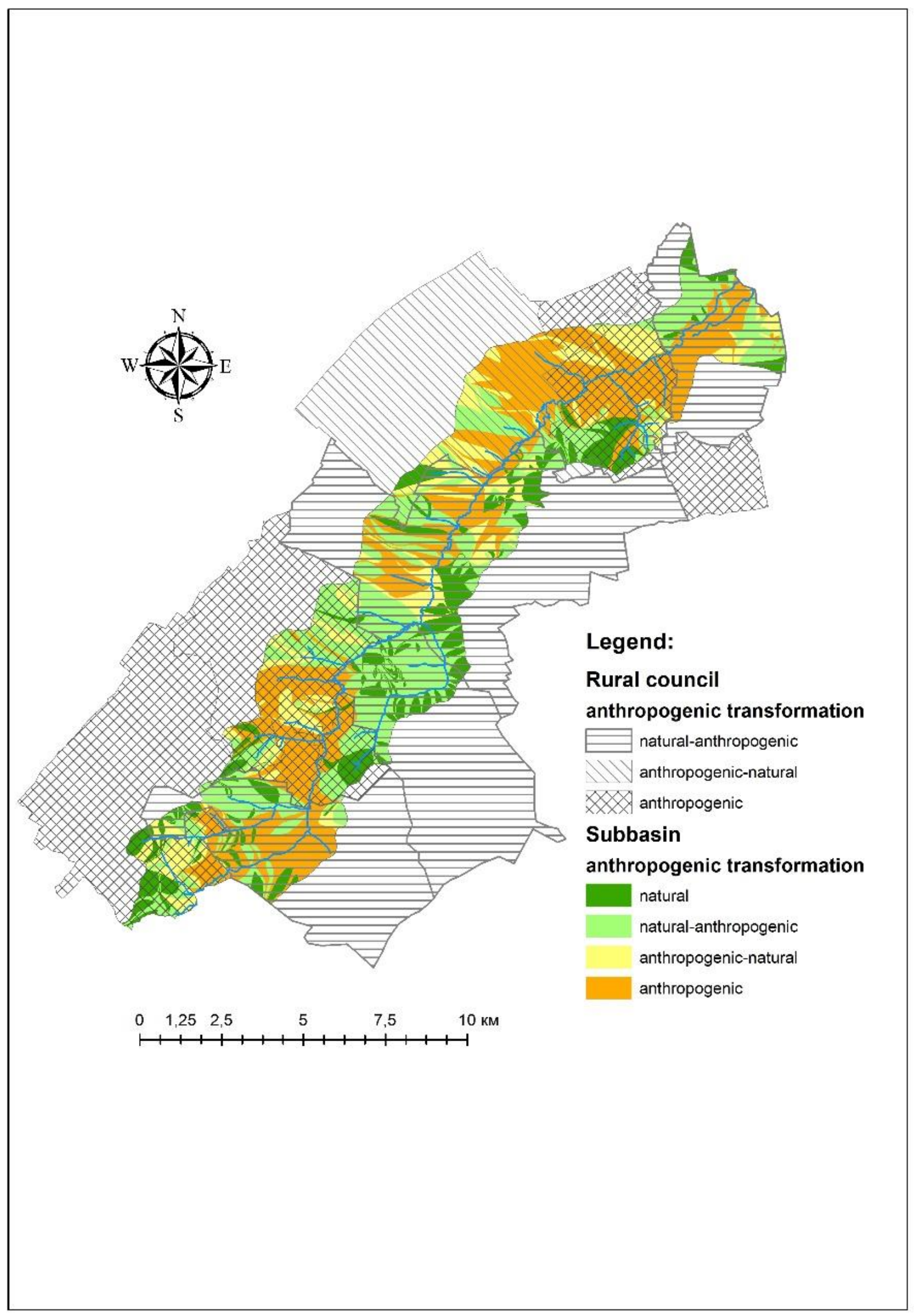

Fig. 1. Anthropogenic transformation of the natural environment in the subbasins and administrative units of the RBS Berezhnytsia 


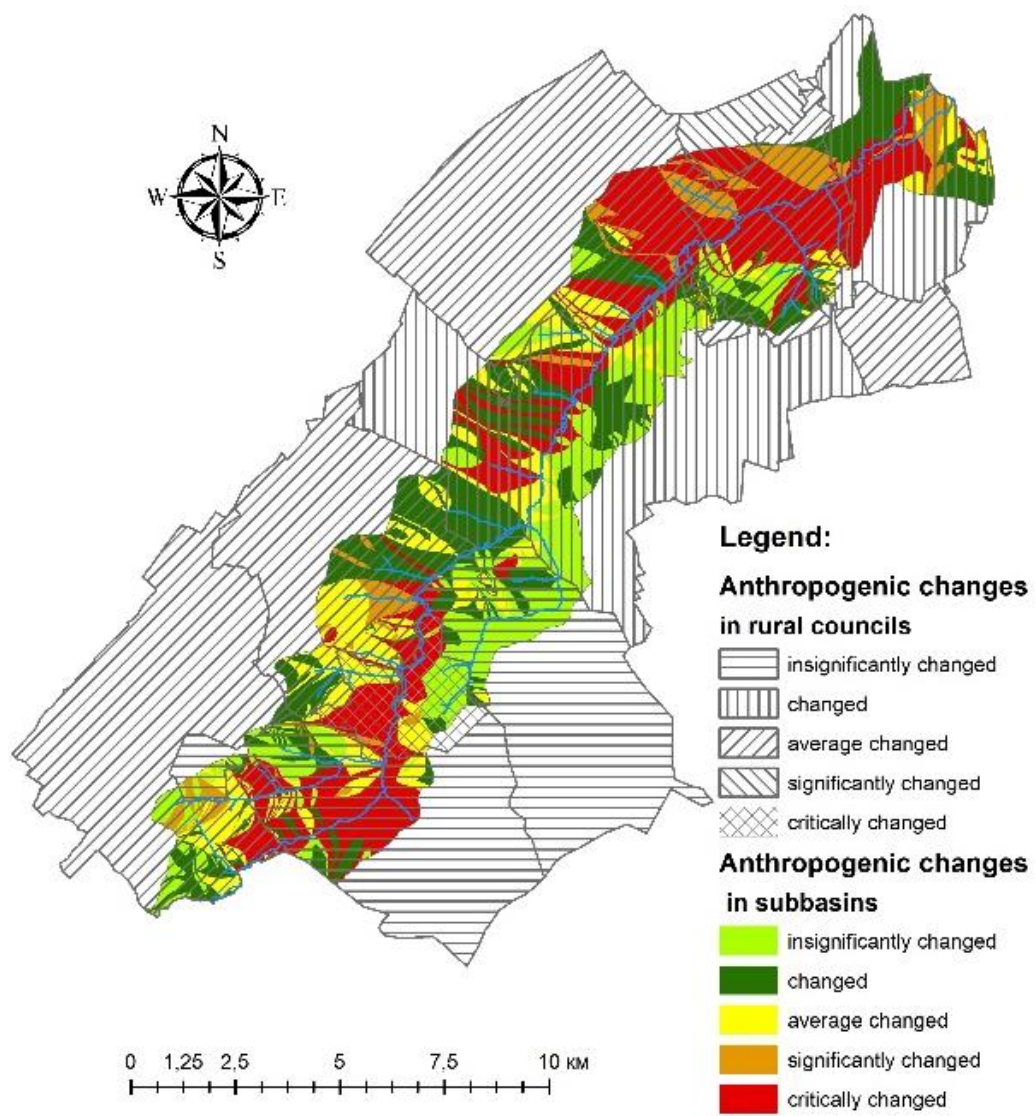

Fig. 2. Anthropogenic changes of the natural environment in the subbasins and administrative units of the RBS Berezhnytsia
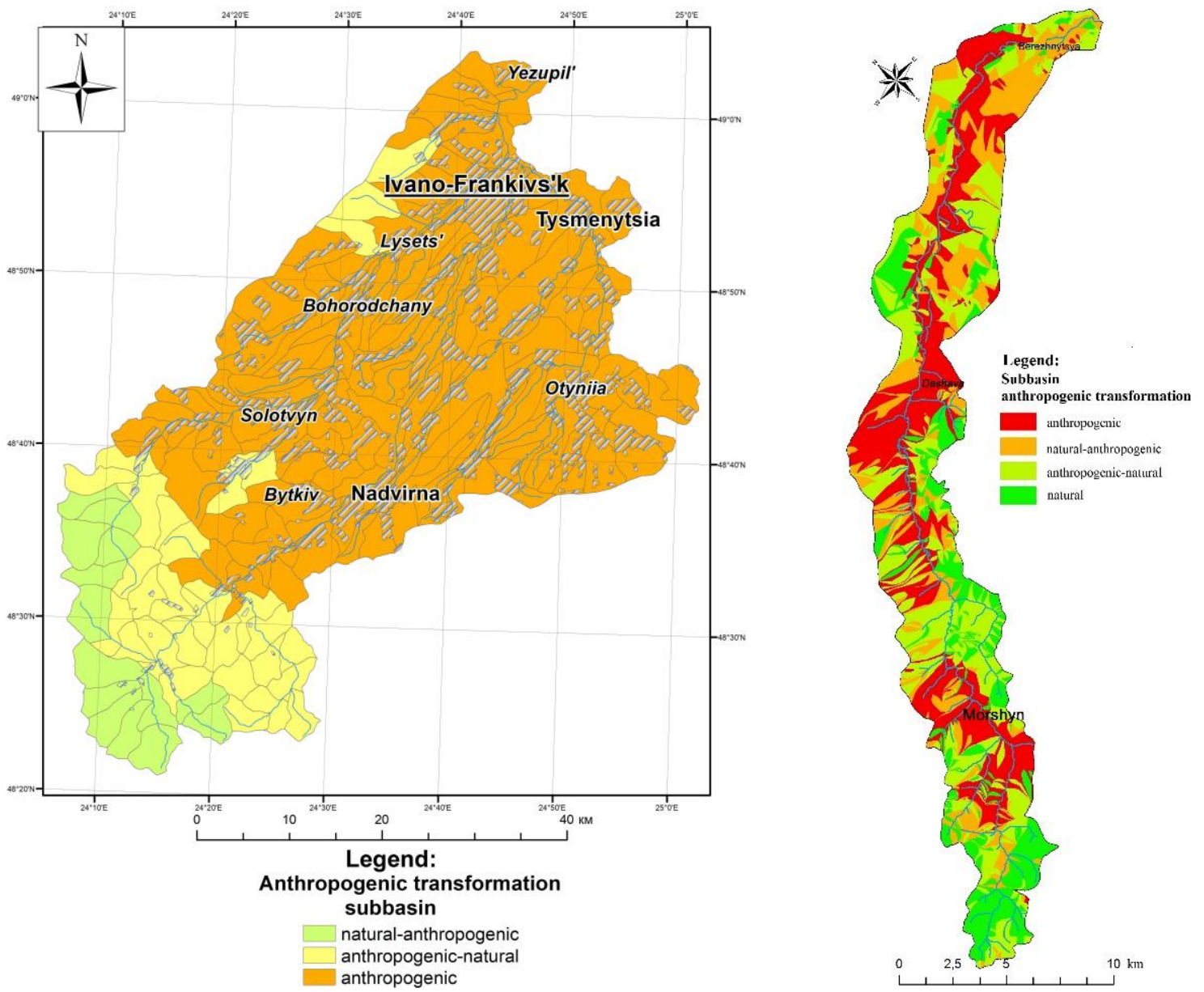

Fig. 3. Anthropogenic transformation of the river-basin systems of Bystrytsia and Berezhnytsia (calculated by the authors according to F.M. Milkov's method) 

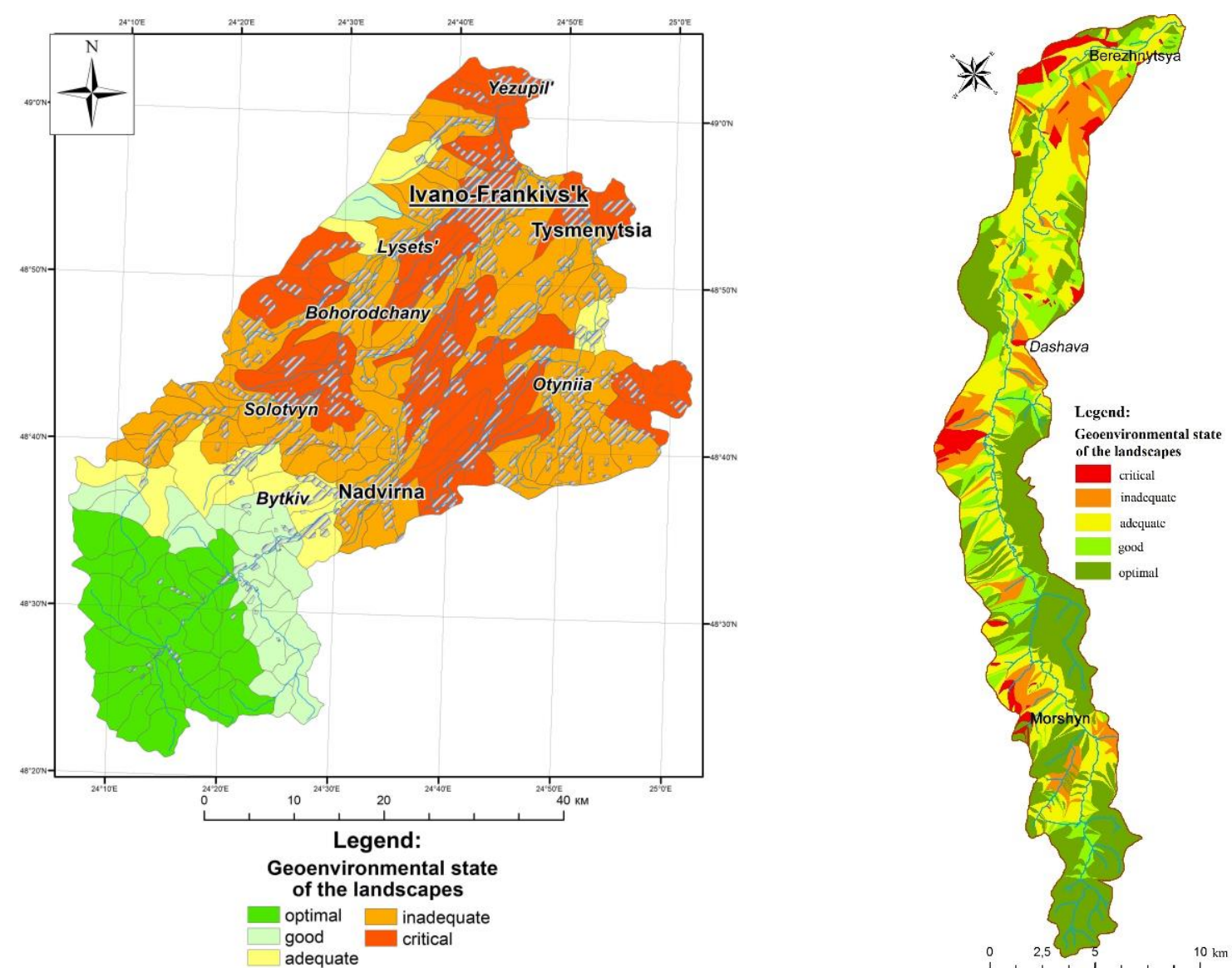

Fig. 4. Geoenvironmental state of agro-landscapes in the rivers-basin systems of Bystrytsia and Berezhnytsia (calculated by the authors according to the method by N. M. Ridey and D. L. Shofolov)
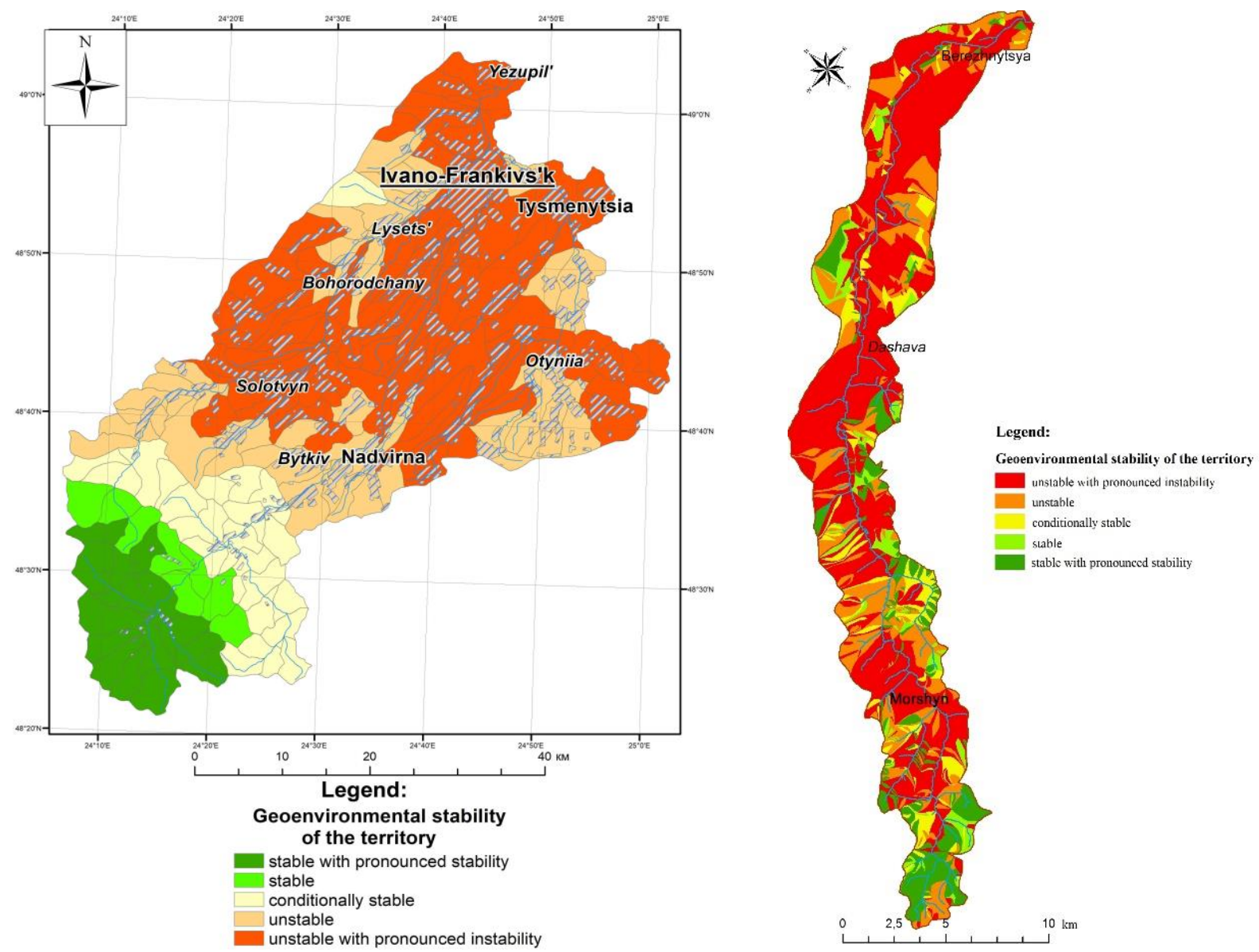

Fig. 5. Geoenvironmental stability of the RBS landscapes of Bystrytsia and Berezhnytsia (calculated by the authors according to the method by E. Klementova and V. Heinige) 

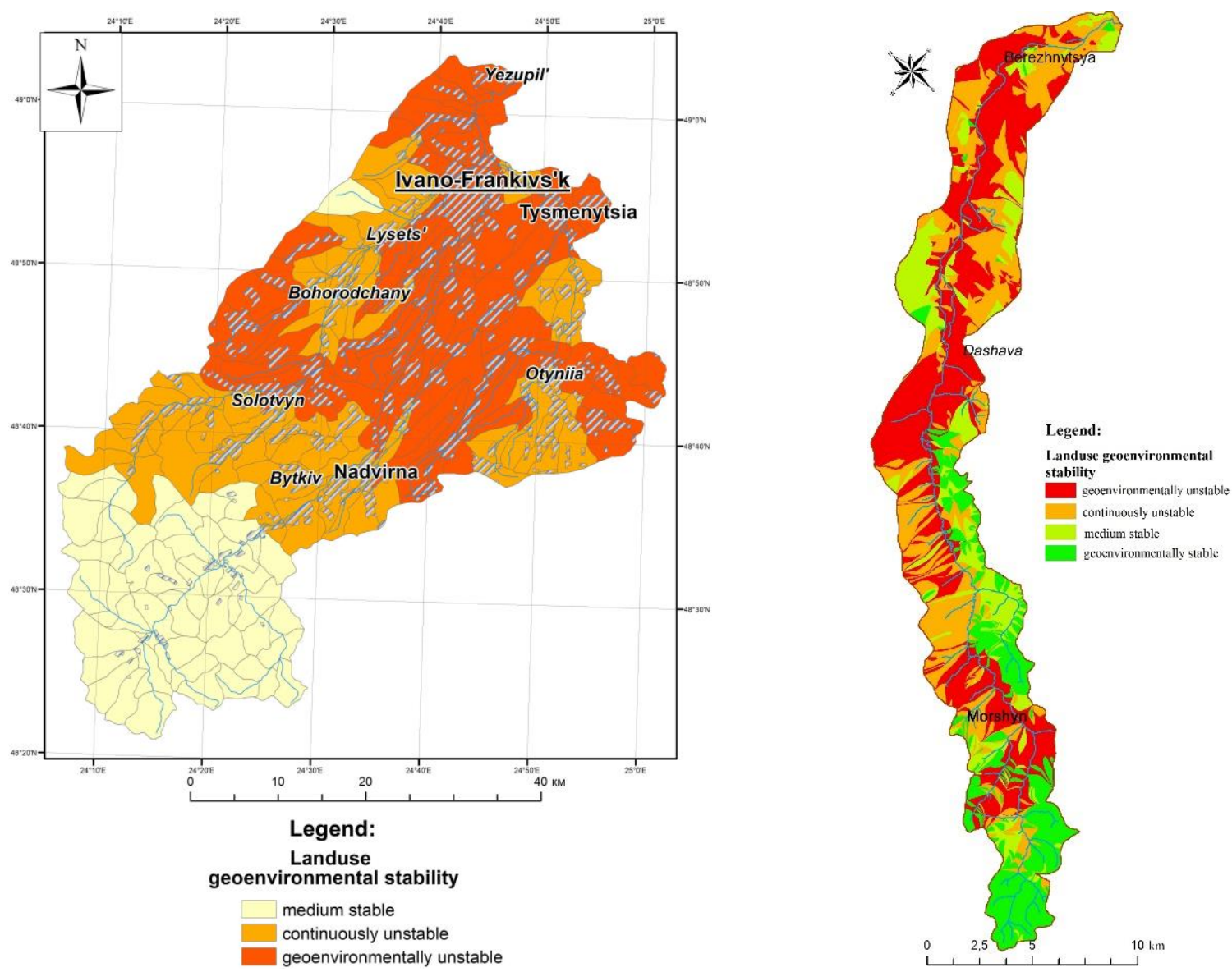

Fig. 6. Geoenvironmental stability of the river basin systems of Bystrytsia and Berezhnytsia (calculated by the authors according to P.P. Barshchevsky's methodology)
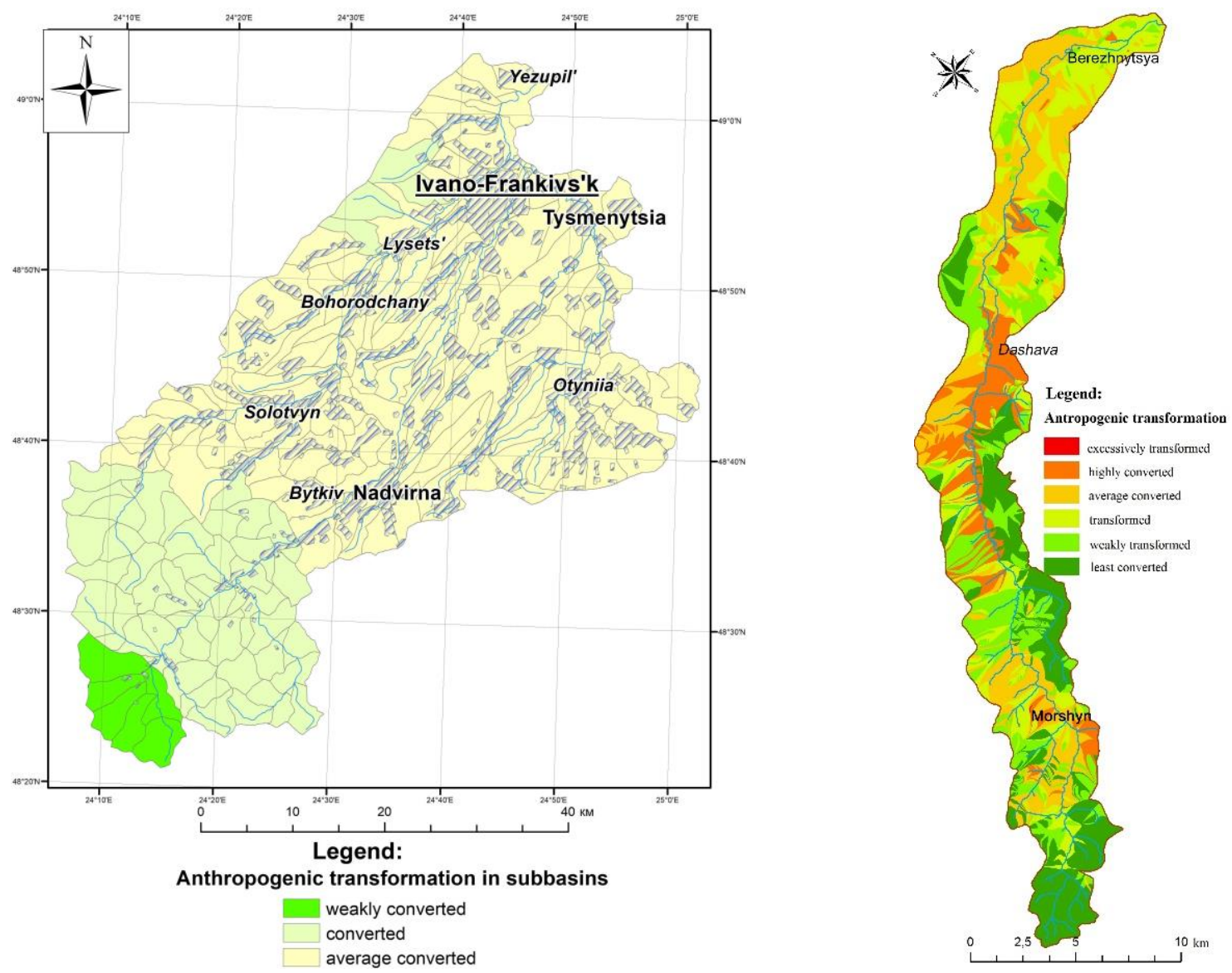

Fig. 7. Anthropogenic transformation of the river-basin systems of Bystrytsia and Berezhnytsia (calculated by the authors according to the method by A.M. Tretyak) 

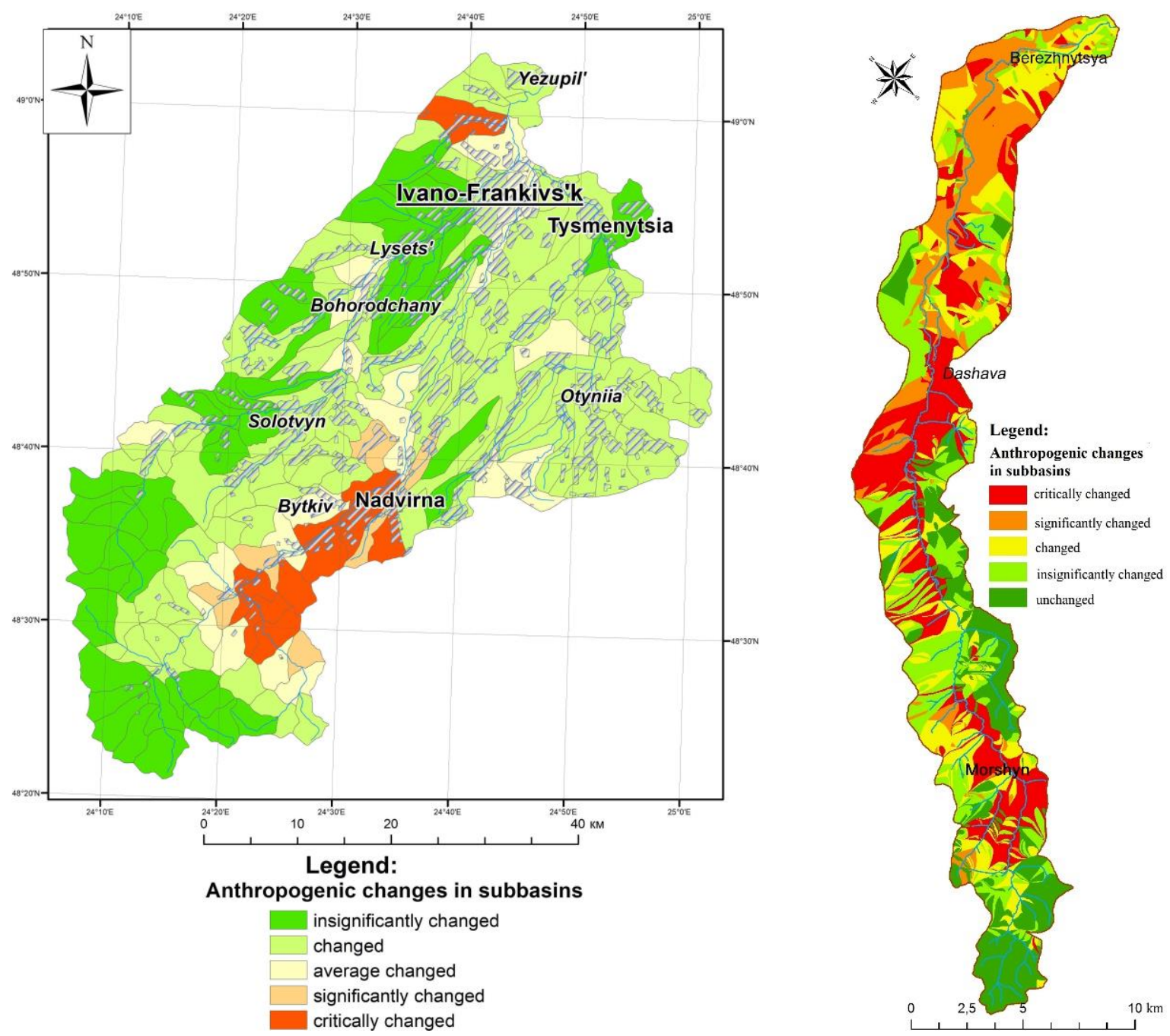

Fig. 8. Anthropogenic transformation of the river-basin systems of Bystrytsia and Berezhnytsia (calculated by the authors according to P.G. Shyshchenko's method)

the latter are represented by the most cultivated subbasins (in the middle part of the basin system).

The created models show that the method of P.G. Shyshchenko allows to more accurately reflect the situation with anthropogenic transformations of the natural environment in the basin, since, apart from the consideration of anthropogenic pressure, the state of agrolandscapes, and the balance and stability of land use (reflected on other models we have created), it also provides their ranking on the depth of the transformation of their environment. Therefore, in our opinion, this model is more accurate.

In the basin system of the Berezhnytsia River, sub-basins of higher ranks, located in the lower part of the basin are strongly over-transformed. This situation has arisen due to their much greater population and the proportion of arable land. In particular, the fourth part of the studied basin is occupied by over-transformed sub-basins, which concentrate along the middle course of the Berezhnytsia River (mostly on the left bank).

In the lower part of the basin, they are represented by the most cultivated sub basins of the reclamation network. Weakly transformed subbasins (aproximately $20 \%$ of total subbasin number) were formed on forest lands that were cut down and in the wetlands of the lower part of the basin, where the share of arable lands (in particular, in the mouth area) decreased and in the low populated areas of the left bank. The smallest anthropogenic changes affected subbasins which occupy $8 \%$ of the territory, that are mostly located within forest lands.

Another distribution of anthropogenic transformation indicators is observed in the basin of the Bystrytsia river. In contrast to the Berezhnytsia river basin, in the Bystrytsia basin industrial lands are present where the environment is affected the most. The presence of a significant number of built-up land, land under transport and communication facilities, technical infrastructure, in conjunction with the lands of factories, quarries and areas for oil extraction, resulted in the location of the most transformed sub-basins in the watersheds (in the northern part of the basin) and above the town of Nadvirna and Bykiv settlement. It is worth notion that a significantly higher level of transformation is observed in the basin of Bystrytsia Nadvirnianska river and after its merging with Bystrytsia Solotvynska. 
Conclusions. 1. The features of quantitative analysis methods of assessing the transformation processes in basin systems, based on different conceptual approaches are revealed. Particular attention is paid to the verification of the most frequently used methods by A.M. Tretyak and P.G. Shyshchenko, their disadvantages and advantages being determined depending on the purpose of the study.

2. In the case study of the rivers and basins of Bystrica and Berezhnytsia (right tributaries of the Dniester river within the Lviv and Ivano-Frankivsk regions), the choice of subbasins of the thalweg network and lower rank subbasins as natural structural units, where it is expedient to determine the level of anthropogenization of the natural environment, is substantiated. The utility of using remote sensing data as the basis for analyzing the state and scale of anthropogenic transformation of natural geosystems in river basins of various ranks is emphasized.
3. A series of digital cartographic models that display the anthropogenic pressure on the riverbasin systems of Berezhnytsia and Bystrytsia have been created and analyzed. A number of common traits have been identified due to the physical geography features of river basins, in particular, the increase in the level of anthropogenization of the natural environment from the headwaters to the river mouth. The minimal amounts of such influence are observed in the mountainous parts and they increase in settlements and in the zones of reclamation channels functioning. The features of the subbasin geosystems state due to different types and intensity of economic influence on them in plain and mountainous parts of the studied basins are determined. A set of measures aimed at improving the geoenvironmental state of the sub-basins of the studied river basin systems of Bystrytsia and Berezhnytsia and ensuring the rational use of their natural resources are proposed.

\section{References}

1. Борщевський П. П. Підвищення ефективності використання, відтворення $і$ охорони земельних ресурсів регіону / П. П. Борщевський, М. О. Чернюк, В. М. Заремба. - К. : Аграр. наука, 1998. - 240 с.

2. Боярин М. В. Конструктивно-географічні основи природокористування в басейні річки Західний Буг / М. В. Боярин // Науковий вісник Волинського начіонального університету ім. Лесі Українки - Луиььк, 2010-Випуск №15. - C.164-168.

3. Вишневський В. I. Антропогенний вплив на річки України. : автореф. дис. на здобуття наук. ступеня доктора геогр. наук : спец. 11.00 .01 «Конструктивна географія та раціональне використання природних ресурсів» / В.І. Вишневський. - Львів, 2003. - 35с.

4. Денисик Г. І. Антропогенні ландмафти Правобережної Украӥни Вінниця: Арбат, 1998. - 242 с.

5. Дубіс Л.Ф. Структурна організаџія та функиіонування річкових систем гірської частини басейну Тиси / Автореферат дисертації на здобуття наук. ступеня канд. географ.наук. - Львів, 1995. - 25 с.

6. Іванов 6 . А. Історико-географічні та ландмафтно-динамічні аспекти трансформації природногосподарських систем гірничопромислових територій / С. А. Іванов, І. П. Ковальчук // Наук. записки Вінниц. держ. пед. ун-ту ім. М. Кочңюбинського. Серія : Географія. - Вінниця : 2007. - Вип. 14. - С. 15-20.

7. Казаков Л. К. Ландшафтоведение с основами ландшафтного планирования: учеб. пособие для студ. высш. учеб. заведений / Л. К. Казаков. -2-е изд., испр. - М. : Издательский центр «Академия», 2008. - 336 с.

8. Кирилюк О. Визначення антропогенного навантаження на басейн малої річки / О. Кирилюк // Молодь у вирішенні регіональних та транскордонних проблем екологічної безпеки: Мат. 5 міжнар. наук. конф. (Чернівиі, 5-6 травня 2006 року). - Чернівиі: Зелена Буковина, 2006. - С. 327-333.

9. Клементова Е. А. Оиенка экологической устойчивости сельскохозяйственных ландшафтов: текст. / E. A. Клементова, В. Гейниге // Мелиораџия и водное хозяйство. - Москва :1995. - № 6. - С. 33-34.

10. Ковальчук A.I. Атласне картографування річково-басейнових систем: монографія / А.І.Ковальчук, І.П.Ковальчук / за наук. ред. проф. І.П.Ковальчука. - Л.: Простір-М, 2018. - 348 c.

11. Ковальчук I. П. Наукові засади досліджень деградаџійних процесів у річкових системах Подільської височини / І. П. Ковальчук // Дослідження малих річок, аналіз проблеми, пропозичї // Матеріали Всеукраӥнської науково-практичної конферениії «Дослідження, відтворення та охорона малих річок». - Хмельницький: ТОВ «Tріада-M», 2005. - C. 63-75.

12. Ковальчук І.П. Аналіз трансформаційних прочесів басейнів малих рік верхньої частини сточища Дністра / I. П. Ковальчук, О. І. Швецьь, Ю. М. Андрейчук // Географічна наука і практика: виклики епохи: Матеріали міжнародної наукової конферениї, присвяченої 130-ти річчю географії у Львівському університеті. Львів: Видавничий иентр ЛНУ імені Івана Франка, 2013. - Том 3. - С. 199-203.

13. Койнова І. Б. Антропогенна трансформація ландиафтних систем західної частини Волинського Полісся : автореф. дис. на здобуття наук. ступеня канд. геогр. наук : спец. 11.00 .01 «Конструктивна географія та раціональне використання природних ресурсів» / І. Б. Койнова. - Львів : Вид-во ЛНУ ім. І. Франка, 1999. $24 \mathrm{c}$.

14. Круглов I. С. Природні геоекосистеми басейну верхнього Західного Бугу / I. С. Круглов // Наукові записки Тернопільського національного педагогічного університету імені Володимира Гнатюка. Серія : Географія. 2015. - № 2. - C. 165-173. 
15. Лихо Е.А. Оптимизация ландшафтной территориальной структуры бассейнов мальх рек Полесья Украины / Академику Л.С. Бергу - 140 лет: Сборник научных статей. - Бендеры: Eko-TIRAS, 2016. - C. 158-161.

16. Мильков Ф.Н. Антропогенные ландшафты: структура, методы и прикладне аспекты изучения. Сб. науч. трудов / Под ред. Ф.Н. Милькова. - Воронеж: Изд-во ВГУ, 1988. - 144c.

17. Михнович А. Структура річкових систем басейну Верхнього Дністра та ї̈ трансформація під впливом природно-антропогенних факторів / А. Михнович // Вісн. Львів. ун-ту. Сер. географ. - Львів, 1998. - Вип. 21. C. 161-167.

18. Петровська М.А. Очінка впливу землекористування на геоекологічну ситуацію Сколівського району Львівської області / Л. Курганевич, М. Петровська // Наукові записки Тернопільського національного педагогічного університету імені Володимира Гнатюка. Серія: географія. - Випуск 38. - Тернопіль: СМП «Тайп». 2015. C. 180-187.

19. Пилипович О.В. Геоекологія річково-басейнової системи Верхнього Дністра : монографія / О.В.Пилипович, І.П.Ковальчук / за науковою редакцією професора І.П.Ковальчука. - Львів - Київ : ЛНУ імені Івана Франка, 2017. $-284 \mathrm{c}$.

20. Приходько М.М. Екобезпека природних і антропогенних геосистем: проблеми, иілі, пріоритети / М.М. Приходько // Наукові записки Тернопільського національного педагогічного університету ім. В. Гнатюка. Серія: географія. Спеціальний випуск: Стале природокористування: підходи, проблеми, перспектива. - Тернопіль: CMП "Taün", 2010. - № 1 (вun. 27). - C. 219-225.

21. Рідей Н. М. Екологічна стандартизація для забезпечення сталого землекористування та охорони земель / Н. М. Рідей, Д. Л. Шофолов // Людина і довкілля. Проблеми неоекології. - Харків, 2009 - Випуск 11(12). - C. 41-50.

22. Сорокіна Л. Ю. Концептуальні засади дослідження ландмафтів, щзо перебувають під впливом техногенних об’єктів / Л.Ю. Сорокіна // Укр. геогр. журн. - 2009. - № 1. - С. 3-8.

23. Сухий П.О. Оиінювання антропогенного впливу на басейнові системи / П.О. Сухий, Я.П. Скрипник, І.С. Березка // Науковий вісник Чернівеиького університету. Географія. -Вип. 612-613. - Чернівиі, 2012. - C. 166-168.

24. Третяк А.М. Методичні рекомендації оцінки екологічної стабільності агроландшафтів та сільськогосподарського землекористування / А.М.Третяк, Р.А.Третяк, М.І. Шквир - К.: Ін-т землеустрою УААН, 2001. $16 \mathrm{c.}$

25. Швець О.І. Трансформачійні процеси у басейнових геосистемах правобережної притоки Дністра - р. Бережниця та методи їх оцінювання і картографування / І. П. Ковальчук,О. І. Швець, Ю. М. Андрейчук // Фізична географія та геоморфологія : Міжвідомчий науковий збірник. - К. : ВГЛ “Обрії”, 2013. - Вип. 2 (70). - C. 282-294.

26. Шищенко П. Г. Прикладная физическая география / П. Г. Шищенко. - К.: Вища школа, 1988. - С. 44.

27. Шищенко П. Г. Принципы и методы ландшафтного анализа в региональном проектировании : монографія. I Шищенко П. Г. - Киев : Фитосоциоцентр, 1999. - 284 c.

28. Batista de Jesus J. Methodology for automatically delimiting permanent preservation areas along water courses the use of GIS in the hydrological basin of the Sergipe river, Brazil [Електронний pecypc] / J. Batista de Jesus, B. Barros de Souza / Universidade Federal de Sergipe, Programa de Pós-Graduação em Agricultura e Biodiversidade, São Cristóvão, SE - Brasil, 2016. - Режuм docmyny: http://www.scielo.br/pdf/rarv/v40n2/0100-6762-rarv-40-020229.pdf.

29. Hossain F. Advancing river modelling in ungauged basins using satellite remote sensing: the case of the GangesBrahmaputra-Meghna basin [Електронний ресурс] / F. Hossain // International Journal of River Basin Management. - Volume 14, Issue 1, 2. - January 2016. - Pp. 103-117. - Pежuм docmyny: https://www.tandfonline.com/ doi/full/10.1080/15715124.2015.1089250.

30. Lautze J. The Zambezi River Basin. Water and Sustainable Development [Електронний pecypc] / J. Lautze, Z. Phiri, V. Smakhtin and D. Saruchera // Earthscan Series on Major River Basins of the World, 2017. - Peжuм docmyny: $\quad$ https://www.scopus.com/record/display.uri? eid=2s2.085013391398\&origin=resultslist $\quad \&$ sort $=$ plf$f \& s r c=s \&$ sid $=225 f 3 a 7 f 399 b 0 e 4 b 0 a a 533134 c 2 a 067 b \&$ sot $=a \& s d t=a \& s l=57 \& s=\% 28 Z a m b e z i+$ River + Basin ++ Atla $s+$ of +the +changing + Environment $29 \&$ relpos $=16 \&$ citeCnt $=2 \&$ searchTerm $=$

31. Li Jiaye. An Efficient Method for Mapping High-Resolution Global River Discharge Based on the Algorithms of Drainage Network Extraction [Електронний pecypc] / Li Jiaye, Li Tiejian, Liu Suning, Shi Haiyun // Water. Open Access Journal, 2018. Режим достyny: https://www.mdpi.com/2073-4441/10/4/533

32. Lu Ling. Mapping the Soil Texture in the Heihe River Basin Based on Fuzzy Logic and Data Fusion [Електронний pecypc] / Lu Ling, Liu Chao, Li Xin, Ran Youhua // Sustainabilityr. Open Access Journal, 2017. - Pежим достуny: https://www.mdpi.com/2071-1050/9/7/1246.

33. Szpikowski Józef. Geomorphological effects of river valleys anthropogenic transformations in the Perznica catchment during the last 200 years (Drawsko Lakeland, Parsęta River basin) [Електронний ресурс] / Józef Szpikowski // Quaestiones Geographicae 30(1), 2011. - Pежuм docmyny: https://content.sciendo.com/view/journals/quageo/30 /1/article-p105.xml? rskey=VOrorX\&result $=1$

34. Zambezi River Basin: Atlas of the Changing Environment (2012) [Електронний ресурс]. - Режим доступу: https://gridarendalwebsite.s3.amazonaws.com/production/documents/:s_document/145/original/ZambeziAtlas_scre en.pdf? 1483646695

Authors Contribution: All authors have contributed equally to this work. 
UDC 911.2:911.9:528.9

Ivan Kovalchuk,

Doctor of Sciences (Geography), Professor, Head of the Department of Geodesy and Cartography,

National University of Life and Environmental Sciences of Ukraine,

17 Vasylkivska St., Building 6, Kyiv, 03040, Ukraine,

e-mail: kovalchukip@ukr.net, https://orcid.org/0000-0002-2164-1259;

Oksana Mykytchyn,

$\mathrm{PhD}$ (Geography), Senior Lecturer, Ivan Franko State Pedagogical University of Drohobych,

23 T. Shevchenko St., Drohobych, Lviv region, 82100, Ukraine,

e-mail: omykytchyn@ukr.net, https://orcid.org/0000-0002-8146-5947;

Andrii Kovalchuk,

PhD Student, Taras Shevchenko National University of Kyiv,

2a Akad. Glushkov Av., Kyiv, SME-680, Ukraine,

e-mail: kovalchuk94a@gmail.com, https://orcid.org/0000-0001-6448-4727

\section{GEOINFORMATION MODELING OF ANTROPOGENIC TRANSFORMATION OF THE BASIN GEOSYSTEMS (CASE STUDY OF DNISTER RIGHT TRIBUTARIES)}

The purpose of the article is to analyze anthropogenic transformation of river-basin geosystems of the outer Subcarpathian region by geoinformational modeling tools using various methods of quantitative estimation of anthropogenic pressure; comparison of modeling results on the basis of administrative-territorial and natural units, selection of optimal structural units for the study of anthropogenic changes in basin geosystems.

Research methods. The features of estimation methods of anthropogenic transformation level of territorial complexes, based on various conceptual approaches to the study of anthropogenic changes in the components of the environment were investigated. In particular, the article compares methods of F.M. Milkov, P.G. Shyshchenko, E. Klementova and V. Geinige, P.P. Borschevsky, M.V. Boyarin, I.P. Kovalchuk, N.M. Ridey and D.L. Shofolov, A.M. Tretyak and others and by the means of geoinformation modeling of riverbasin geosystems (namely, the case study of the outer Subcarpathian Dniester tributaries) shows the degree of representativeness of the results produced by each of them. It is noted that the technique by P.G. Shyshchenko allows to more accurately reflect the state of anthropogenic transformation of the river-basin system's natural conditions

Results. A range of digital cartographic models was developed to evaluate and compare anthropogenic transformation level of the two Carpathian basin systems and to identify similar and distinctive features of the state and the transformation level of the basin systems' natural environment andstability of agricultural and forest landscapes in the studied basin geosystems. In particular, the study has revealed that the anthropogenic transformation of the outer Carpathian river basins is rising downstream. In the upper parts of the basins, it manifests itself in deforestation, while in the lower parts agricultural influence dominates. In addition, the index of anthropogenic transformation is rising with an increase in the order of sub-basins. The worst conditions of agro-landscapes are observed in the reclaimed valleys of the main rivers and their tributaries (due to the considerable level of plowing in the plain parts of the basins due to low fertility of soils, high levels of their acidity, degradation processes and chemical pollution). Stable territories are inherent exclusively in sub-basins which remain in their natural state or bear only traces of human activity. Settlements, which influence adjacent areas, are characterized by unsustainable land use. As for anthropogenic transformation, in the basin geosystem of the Berezhnytsia river its indicators increase upwards due to an increase in the share of arable land. On the contrary, in the basin of Bystrica much more land is occupied by industrial facilities, which affect the components of the geosystem the hardest. In this regard, the largest values of nature anthropogenic transformation indicators are found in the northern part of the basin and upstream of the city of Nadvirna and the town of Bykiv.

Scientific significance. Case study of the administrative regions and the river basin located within them reveals the advantages of studying the geoenvironmental state of the territories according to their natural geographic taxonomic units, which allows to determine the most strained areas in geosystems. Particular attention is paid to the choice of optimum sized geospatial objects during the study of diverse basin systems. River sub-basins of the third order (according to the classification scheme of A. Strahler) were chosen to this purpose. Their size corresponds to that of the combined territorial communities' area. The importance of formation a database that reflects on the state of the geospatial entities under study is emphasized. For this purpose, it is appropriate to convey the structure of land use, represented by indices of different land cover 
and land use types (protected areas, forest covered areas, swamps and wetlands, meadows, gardens and vineyards), arable land, land under rural and urban development, natural objects modified by human activities (reservoirs, ponds, channels), land utilized by industry and transport in each investigated object. The article shows that the best solution to this problem is provided by the processing of high-resolution spatial (in panchromatic and multispectral) remote sensing data. The most appropriate in this case are QuickBird satellite imagery, designed to create and update topographic maps and plans, to make inventories of forests and agricultural lands and to assess their condition, therefore allowing mapping of land use types that are not identified in statistical inventories.

Practical significance. The results of this work will be helpful in selecting the specific technique allowing the most complete representation of anthropogenic transformation of natural objects; in choosing the most optimal spatial units to carry out the analysis and, accordingly, to fill in the database. The developed models reveal the most anthropogenically loaded parts of river-basin geosystems of the outer Subcarpathian region, which is essential for the extrapolation of the obtained results to other right tributaries of the Dniester River.

Keywords: river-basin geosystems, geoinformation modeling, land use structure, antipogenic transformation.

\section{References}

1. Borschevsky, P.P., Chernyuk, M.O., Zaremba, V.M., Korenyuk, P.I., \& Knyazhiv, V.O. (1998). Improving the efficiency of use, reproduction and protection of land resources of the region. Kyiv: Agrarian Science, 240.

2. Boyarin, M. V. (2010). Constructive-geographical Basis of Management in the West Bug River Basin. Scientific Bulletin of Volyn Lesya Ukrainka National University: Geographical science, 15, 164-168.

3. Vishnevskiy, V.I. (2003). Anthropogenic impact on the rivers of Ukraine. Extended abstract of Doctor's thesis, Lviv, 35.

4. Denisik G.I.(1998). Anthropogenic landscapes of the Right-bank of Ukraine. Vinnitsa, Arbat, 292 .

5. Dubis, L.F. (1995). Structural organization and functioning of river systems of the mountainous part of the basin Tisza. Extended abstract of candidate's thesis, Lviv, 25.

6. Ivanov, Ye. A., \& Kovalchuk, I.P. (2007). Historical-geographical and landscape-dynamic aspects of the transformation of natural-economic systems of mining areas. Vinnitsa Scientific notes of. M. Kotsyubinsky Vinnitsa State Pedagogical University. Series: Geography, 14, 15-20.

7. Kazakov, L.K. (2007). Landscape science with the basics of landscape planning. Moscow: Akademiya, 335.

8. Kyrylyuk, O.V (2010). Estimation of small river basins transformation as step to determination of anthropogenic changes of hydromorphological terms. Hydrology, hydrochemistry and hydroecology, 18, 283-289.

9. Klementova, E., \& Geynige, B. (1995). Assessment of the environmental sustainability of the agricultural landscape. Irrigation and Water Management. 5, 24-35.

10. Kovalchuk, A.I., \& Kovalchuk, I.P.(Ed.). (2018). Atlas mapping of river-basin systems. Lviv: Prostir-M, 348.

11. Kovalchuk, I.P. (2005). Scientific research principles of degradation processes in river systems of the Podolsk upland. Research, reproduction and protection of small rivers. Materials of the All-Ukrainian scientific-practical conference (pp. 63-75). Khmelnytsky.

12. Kovalchuk, I.P., Shvets, O.I., \& Andreychuk, Yu.M. (2013). Analysis of transformation processes of small river basins of the upper part of the Dnister river basin. Geographical science and practice: challenges of the era: Materials of the international scientific conference devoted to the 130th anniversary of geography in Lviv University, 3 (pp. 199-203). Lviv.

13. Koynova, I.B. (1999). Antropogenic Transformation of the Landscape Systems of the Western Part of Volynske Polessia. Extended abstract of candidate's thesis, Lviv, 24.

14. Kruhlov, I.S. (2015). Natural geoecosystems of the upper Western Bug basin. Scientific Notes Ternopil National Pedagogical University named after Volodymyr Hnatyuk. Series: Geography, 2, 165-173.

15. Licho, E.A. (2016). Optimization of the landscape territorial structure of the basins of the small rivers of Polesie Ukraine. Academician L.S. Berg - 140 years: Collection of scientific articles (pp. 158-161). Bendery.

16. Milkov, F.N. (1988). Natural-anthropogenic landscapes as a special category of natural complexes. Anthropogenic landscapes: structure, methods and applied aspects of their study, 4-13.

17. Mykhnovych, A.V(1998). Structure of river systems of the Upper Dniester basin and its transformation under the influence of natural and human factors. Visnyk of Ivan Franko National University of Lviv: Geography, 21, 161-167.

18. Petrovska, M., \& Kurhanevych, L. (2015). Assessment of the impact of land use on geoecological situation in Skole subregion of Lviv region. Scientific Notes Ternopil National Pedagogical University named after Volodymyr Hnatyuk. Series: Geography,38, 180-187.

19. Pylypovych, O.V., \& Kovslchuk, I.P. (Ed.) (2017). Geoecology of the Upper Dniester river-basin system. Lviv-Kyiv: LNU of Ivan Franko, 284.

20. Prykhodko, M. M. (2010). Ecological safety of natural and anthropogenic geosystems: problems, aims, advantages. Scientific Notes Ternopil National Pedagogical University named after Volodymyr Hnatyuk. Series: Geography $1(27), 219-225$. 
21. Ridey, N.N., \& Shofolov, D. L. (2009). Ecological standardization for sustainable land use and land protection. Man and environment. Problems of neoecology, 11 (12), 41-50.

22. Sorokina, L. Yu. (2009). The conceptual foundations of the investigation of landscapes influenced by technogenic objects. Ukrainian Geographic Magazine, 1, 3-8.

23. Suchij, P.O., Skrypnyk, Y.P., \& Berezka, I.S. (2012). Assessment of anthropogenic impact on the basin system. Scientific Herald of Chernivtsi University: Geography, 612-613, 166-168.

24. Tretiak A.M., Tretiak, R.A., Shkvyrya, M.I. (2001). Guidelines for the assessment of environmental sustainability of agricultural landscapes and agricultural land use. Kyiv, 16.

25. Kovalchuk, I.P. Shvets, O.I., \& Andreychuk, Yu.M. (2013). Transformation processes in the basin geosystems of the Dnister right-bank - Berezhnytsa river and methods of their assessment and mapping. Physical geography and geomorphology: Interdepartmental scientific collection, 2 (70), 282-294.

26. Shishchenko, P. G. (1988). Applied Physical Geography. Kyiv, Parent publisher publishing association "Vishcha School", 192.

27. Shishchenko P.G. (1999). The principles and methods of landscape analysis in regional planning. Kiev: Fitosotsiotsentr, 284.

28. Batista de Jesus, J., \& Barros de Souza, B. (2016). Methodology for automatically delimiting permanent preservation areas along water courses - the use of GIS in the hydrological basin of the Sergipe river, Brazil. Available at http://www.scielo.br/pdf/rarv/v40n2/0100-6762-rarv-40-02-0229.pdf.

29. Hossain F. (2016). Advancing river modelling in ungauged basins using satellite remote sensing: the case of the Ganges-Brahmaputra-Meghna basin. International Journal of River Basin Management 1(14), $2016,103-117$. Available at https://www.tandfonline.com/doi/full/10.1080/15715124.2015.1089250.

30. Lautze, J., Phiri, Z., Smakhtin, V., \& Saruchera, D. (2017). The Zambezi River Basin. Water and Sustainable Development. Available at https: //www.scopus.com/record/display.uri?eid=2-s2.085013391398\&origin=resultslist $\&$ sort $=$ plf-

$f \& s r c=s \&$ sid $=225 f 3 a 7 f 399 b 0 e 4 b 0 a a 533134 c 2 a 067 b \&$ sot $=a \& s d t=a \& s l=57 \& s=\% 28$ Zambezi + River + Basin ++ Atla $s+o f+$ the + changing + Environment\%29\& relpos $=16 \&$ citeCnt $=2 \&$ searchTerm $=$

31. Li, J., Li, T., Liu S., \& Shi H. (2018). An Efficient Method for Mapping High-Resolution Global River Discharge Based on the Algorithms of Drainage Network Extraction. Water. Open Access Journal. Available at https://www.mdpi.com/2073-4441/10/4/533

32. Ling Lu, Chao Liu, Xin Li, \& Youhua Ran (2017).Mapping the Soil Texture in the Heihe River Basin Based on Fuzzy Logic and Data Fusion. Sustainabilityr. Open Access Journal, 2017. Available at https://www.mdpi.com/2071-1050/9/7/1246].

33. Szpikowski Józef (2011). Geomorphological effects of river valleys anthropogenic transformations in the Perznica catchment during the last 200 years (Drawsko Lakeland, Parsęta River basin). Quaestiones geographicae 30(1), Available at https://content.sciendo.com/view/journals/quageo/30/1/article-p105.xml rskey=VOrorX\&result $=1]$

34.Zambezi River Basin: Atlas of the Changing Environment (2012). Available at https://gridarendalwebsite.s3.amazonaws.com/production/documents/:s_document/145/original/ZambeziAtlas_scre en.pdf?1483646695] 